\title{
Cumhuriyetten Günümüze Sosyal Bilgiler Dersi Öğretim Programlarındaki Coğrafya Konularının Öğretiminde Kullanılan Araç ve Gereçler
}

\author{
Sidal KORKMAZ ${ }^{1}$ \\ Ahmet UYĞUR ${ }^{2}$
}

Geliş Tarihi: 03.05.2021

Kabul Tarihi: 31.05.2021

Doi: $10.47503 /$ jirss. 932262

\section{Özet}

$\mathrm{Bu}$ çalışmanın amacı, Cumhuriyetten günümüze kadar uygulanan ilkokul ve ortaokul sosyal bilgiler dersi öğretim programlarında coğrafya konularının öğretiminde kullanılması önerilen materyallerin geçirdiği gelişim sürecini incelemektir. Araştırmada nitel araştırma yöntemlerinden doküman incelemesi yöntemi kullanılmıştır. Literatür taraması sonucunda elde edilen veriler betimsel analiz tekniği ile analiz edilmiştir. Sonuçlar incelendiğinde; Cumhuriyetin ilanından sonra hazırlanan ilk program olan 1924 İlk Mektep Programında, coğrafya dersinde kullanılması önerilen materyallerin sayıca az ve çeşitliliğinin kısıtlı olduğu görülürken, ilerleyen programlarla birlikte materyal çeşitliliklerinin arttığı görülmektedir. 1968 yılında ise ilk kez sosyal bilgiler adı altında okutulmaya başlanan dersin, coğrafya konularında kullanılması önerilen materyaller kısmında, önceki programlardan farklı olarak güneş sistemi basit modeli gibi farklı materyallerin yer aldığı görülmektedir. 1971 İlkokul Programından 2005 Sosyal Bilgiler Dersi Öğretim Programına kadar materyal çeşitliliklerinde anlamlı bir değişiklik görülmez ve klasikleşmiş materyaller yer alırken, 2005 Sosyal Bilgiler Dersi Öğretim Programında teknolojinin de ilerlemesinin getirdiği etkiyle birlikte dijital araç gereçlerin yer aldığı görülmektedir. Günümüzde öğretimi halen devam eden 2018 Sosyal Bilgiler Dersi Öğretim Programında ise bir önceki programdan farklı olarak birkaç materyalin eklenmesinin yanı sıra, coğrafya öğretimi için programlarda önerilen materyal çeşitliliğinin azaldığı görülmektedir. Çalışmanın sonuçlarına göre; incelenen programların ders kitaplarının da incelenerek, coğrafya konularının öğretimindeki araç gereç kullanım durumunun belirlenmesine yönelik çalışmaların yapılabileceği önerilmektedir.

Anahtar Kelimeler: Sosyal Bilgiler Dersi Öğretim Programları, Coğrafya Öğretimi, Materyal, Araç ve Gereç

\footnotetext{
${ }^{1}$ Yüksek Lisans Öğrencisi, Akdeniz Üniversitesi Eğitim Bilimleri Enstitüsü, Türkiye. sidalkorkmz@gmail.com ORCID ID: 0000-0003-1297-6273

2 Yüksek Lisans Öğrencisi, Akdeniz Üniversitesi Eğitim Bilimleri Enstitüsü, Türkiye. auygurahmet@gmail.com ORCID ID: 0000-0001-9282-2631
}

Atıf künyesi: Korkmaz, S. ve Uyğur, A. (2021). Cumhuriyetten günümüze sosyal bilgiler programlarındaki coğrafya konularının öğretiminde kullanılan araç ve gereçler. Journal of Innovative Research in Social Studies. 4(1),34-47. https://doi.org/10.47503/jirss.932262 


\title{
Tools and Materials Used in the Teaching of Geography Subjects in Social Studies Curriculums from the Republic to Today
}

\author{
Received Date: 03.05 .2021
}

Accepted Date: 31.05 .2021

Doi: $10.47503 /$ jirss. 932262

\begin{abstract}
The aim of this study is to examine the development process of the materials proposed to be used in the teaching of geography subjects in primary and secondary school social studies curriculums from the Republic to the present day. In the research, the document review method was used from qualitative research methods. The data obtained as a result of the literature review in the study was analyzed by descriptive analysis technique. Examination of the results of the research; in the 1924 first school program, the first program prepared after the proclamation of the Republic, it is seen that the materials proposed to be used in the geography course are few in number and limited in diversity, while the diversity of materials increases with the following programs. In 1968, the course, which was first taught under the name of social studies, appears to contain different materials such as a simple model of the solar system, unlike previous programs. While there was no significant change in material diversity from the 1971 primary school program to the 2005 primary school program, and classic materials were included, digital tools were included in the 2005 Social Studies course curriculum, as well as the impact of the advancement of technology. In addition to the addition of several materials in the 2018 Social Studies course curriculum, which is still teaching today, unlike the previous program, the variety of materials recommended in geography teaching programs appears to be decreasing. According to the results of the study, it is suggested that studies can be done to determine the state of use of tools in teaching geography subjects by examining the textbooks of the programs studied.
\end{abstract}

Keywords: Social Studies Curriculums, Geography Teaching, Materials, Tools and Equipment 


\section{GİRiş}

Geçmişten günümüze hayatımızın her alanı birçok sebeple değişikliğe uğramıştır. Bu değişim bazen siyasi bir sebeple, bazen toplumsal bazen de çağın gerekliliklerine uyum sağlamak amacıyla yaşanmıştır. Bu değişimden etkilenen alanlardan biri de eğitimdir. Planlı bir eğitim ise öğretim programları aracılığıyla olmaktadır. Öğretim programı, bir eğitim kademesinde çeşitli sınıf ve derslerde işlenecek konularla ilgili öğretim etkinliklerini içine almaktadır (Demirel, 2013). Cumhuriyetten günümüze birçok öğretim programı hazırlanmıştır. Bu programlar yapıldığı dönemin şartlarını yansıttığı gibi birtakım felsefi akımlardan da etkilenmişlerdir.

Cumhuriyetin ilk yılları olarak adlandırabileceğimiz 1924-1938 yılları arasında kalan programlarda, John Dewey'in maarif raporunun etkisiyle beraber ilerlemecilik eğitim felsefesinin etkili olduğu görülmektedir (Ulubey ve Aykaç, 2017). Yeni bir yönetim anlayışının etkili olduğu bu dönemde programlar, Cumhuriyetin gerekliliklerine uygun olarak düzenlenmiştir. Millet bilincini oluşturmak için eğitim, önemli bir araç olarak görülmüsstür. Mustafa Kemal'in “En önemli ve verimli vazifelerimiz Millî Eğitim işleridir. Bunun için de öğretim programları ona göre düzenlenmelidir." (Palazoğlu, 1999:213, akt. Çetin ve Gülseren, 2003) sözü dönemin eğitim anlayışını açık bir şekilde yansıtmaktadır. Atatürk'ün ölümü sonrası yıllar olarak adlandırabileceğimiz 1938-1948 yılları arasında ki programlarda ilerlemecilik eğitim felsefesi anlayışı devam ederken, bu dönemde yaşanan 2 . Dünya Savaşı gibi hemen hemen tüm ulusları etkileyen bir olay eğitimde de etkisini hissettirmiştir. Öğretmen, öğrenci ve okul sayılarında artış yaşanmış ancak bu artış beklenenden az olmuştur. Bu durumun nedeni savaş yıllarının getirdiği ekonomik ve sosyal sıkıntılardır (Karabacak, 2009). 1949-1998 yılları arasında yaşanan 1960 ve 1980 darbeleri gibi siyasi olayların etkisi dönemin programlarına yansırken, ilerlemecilik eğitim felsefesi anlayışı etkisini sürdürmüştür. 27 Mayıs 1960 darbesi ile beraber darbeyi gerçekleştiren kadroların müdahale etmeye çalıştıkları ilk alanlardan biri eğitim sistemiyken (Kılıç, 2020), 12 Eylül 1980 darbesiyle, ders kitaplarında demokratik değerlerden çok milliyetçi değerlerin ön planda tutulduğu ve farklılıkların arka plana itildiği görülmektedir (Kaya ve Önal, 2019). 2005-2018 yılları arasında ise teknolojinin ilerlemesi ve yapılandırmacı anlayışın programlara hakim olmasıyla beraber yeni bir döneme girilmiştir.

2005 yılında yapılandırmacı anlayışa geçilmesiyle birlikte yeni öğretim yöntem ve teknikleri programlara girmiş, bunun neticesinde derslerde materyal kullanılmasının önemi artmıştır (MEB, 2005). Öğretim materyali, öğretim hedeflerine ulaşmak amacıyla bir takım araçlar kullanılarak yapılan ders etkinliklerini kapsamaktadır (Nalçacı ve Ercoşkun, 2005). Eğitimde materyal kullanımıla birlikte öğretim daha kalıcı ve anlamlı hale gelirken öğretmeni de destekleyerek dersin verimliliğinin artmasına yardımcı olur. Bundan dolayı eğitimde ve öğretimde konuların daha iyi anlaşılmasına ve kavratılmasına yardımcı olmada; konuların temel ve önemli noktalarının belirtilmesinde; bunun yanında öğrencilerin öğrenme isteklerini arttırmada ve dikkatini çekme noktasında, öğretim materyallerinden faydalanılmaktadır (Kaya ve Aydın, 2011). Her geçen gün öğrenmeyi daha kalıcı hale getirmek amacıyla yöntem, teknik ve materyaller geliştirilip kullanılmaktadır. Hemen hemen çoğu dersin kendine göre yöntem ve teknikleri ve öğretimde kullandıkları materyaller bulunmaktadır. Ancak bazı dersler materyal kullanımına daha yatkındır (Şahin, Gençtürk 
ve Budanur, 2007). Tüm branşlarda yararlanılması önemli olan materyallerden en çok faydalanabilecek alanlardan biri de sosyal bilgilerdir.

Sosyal bilgiler; tarih, coğrafya, sosyoloji, psikoloji, hukuk gibi sosyal bilim alanlarını içeren ve içerisine sürekli yeni bilgilerin eklendiği çok disiplinli bir derstir (Yıldız ve Kılıç, 2018). Konusunu insandan alır ve içinde insan hayatının farklı safhalarını barındırır (Kaymak, 2019). Günümüzde 4, 5, 6 ve 7. sinıflarda okutulan sosyal bilgiler dersinin, geçmiş programlara bakıldığında farklı şekilde adlandırıldığ1 görülmektedir. 1924 İlk Mektep Müfredat Programında sosyal bilgiler, "Musahabat-1 Ahlakiye ve Malumat-1 Vataniye" şeklinde adlandırılırken, 1962 yılında "Toplum ve Ülke İncelemeleri" adı altında öğretimi yapılmıştır. 1968 yılında ilk kez "Sosyal Bilgiler" adı kullanılırken, 1985 yılında "Milli Tarih ve Milli Coğrafya" dersleri adı altında öğretimi devam etmiştir. 1998 yılından itibaren ise tekrardan "Sosyal Bilgiler" adıyla okutulmaya başlanmış ve günümüze kadar ismi değişmemiştir (Yalçın ve Akhan, 2019).

Cumhuriyetin ilk yıllarından itibaren hazırlanan sosyal bilgiler programlarında materyal kullanılmasının önemi fark edilmiş olunacak ki hemen hemen her programda materyal kullanımının vurgulandığı görülmektedir. Materyal kullanılmasının gerekliliğinden bahsedilirken bazı programlarda bir materyalin disiplinler arası bir yaklaşımla kullanılabileceğinin de belirtildiği görülmektedir:

" Tarih derslerinde öğretmen, coğrafi etmenlerle tarihi olaylar arasındaki sıkı ilişkiye çocukların dikkatini çekmeli; insanların coğrafi etkiler altında nasıl harekete mecbur kaldiklarını, bu etmenler üzerine de nasıl tesir etmeye çalıştıkların göstermelidir. Öğretmen tarih ile coğrafya dersleri arasında sıkı bir ilişki kurmalı, tarih olaylarının açıklanması sırasında haritalardan da faydalanmalıdır" (MEB, 1948, s. 130) (MEB, 1949, s.92).

Programlarda materyal kullanımı ile ilgili disiplinler arası bir yaklaşım benimsenirken, derslerde kullanılacak materyallerle birlikte bu materyallerin nasıl kullanılacağ bir şekilde yer almıştır:

"Tedrisat esnasinda tarihi levhalar da gösterilecektir. Ĕ̆ger levha yoksa muallim kitaplardan tedarik edebildiği levhalarn ve kartpostalları gösterir. Mektepte tarihi kartlardan mürekkep bir koleksiyon yapilmasi tavsiye olunur" (MEB, 1930, s. 67).

Yukarıda verilen örneklerde de görüldüğü gibi programlarda materyal kullanılmasının gerekliliği üzerinde durulmuş ve sadece yüzeysel olarak kullanılacak materyallerden bahsetmek yerine, nasıl kullanılacağına da değinilmiş, ayrıca diğer derslerle bağlantılı bir şekilde ilerlemesi gerektiğinden de söz edilmiştir. Bu durum geçmişten itibaren programlarda materyal kullanımının önemini göstermektedir.

Sosyal bilgileri oluşturan disiplinler arasında bulunan coğrafya, materyal kullanımı için oldukça uygun bir derstir. Coğrafya dersinin konularının büyük çoğunluğunun soyut olması sebebiyle anlaşılması güçleşmektedir. Bundan dolayı derste kullanılacak materyaller hem öğretmenin işini kolaylaştıracak hem de öğrenciler için daha anlamlı öğrenmeler sağlayacaktır (Kaya ve Aydın, 2011). Seferoğlu (2006: 54), insanların, okuduklarının \%10'unu, işittiklerinin \%20'sini, gördüklerinin \%30'unu, söylediklerinin \%70'ini, görüp, işittiklerinin \%50'sini, yapıp söylediklerinin ise \%90'nını hatırladığını ortaya koymaktadır. $\mathrm{Bu}$ durum öğretimin içine ne kadar fazla duyu organı hitap ederse öğretimin niteliğinin o derece artacağını göstermektedir. Bu da derslerde materyal kullanımının önemini açığa çıkarmaktadır. Coğrafya konuları için yerinde gözlem yapmak oldukça zor bir durumdur. 
Örneğin bir yerin arazi yapısını öğretmek için o yere gitme şansımız olmayabilir. Bunun yerine sınıfa kabartma haritası getirilebilir. Bu da aynı zamanda objeler aracilı̆̆ıla coğrafyanın, öğrencinin ulaşabileceği sınıf ortamına getirilmesine olanak tanımaktadır (Kaya ve Aydın, 2011).

Sosyal bilgiler programlarında coğrafya öğretimi için kullanılacak materyaller, programlarda kapsamlı bir şekilde yer almıştır. Coğrafya öğretiminde materyal kullanımına yönelik 1949 İlkokul Programında şu ifadeler kullanılmıştır:

"Coğrafya derslerinde, çeşitli araç ve gereçlerden geniş ölçüde faydalanlacaktır. Bunlarm mümkün olduğu kadar her öğrenciyi kendi kendine ö̆rrenmeye sevk edecek sayıda olmasina dikkat edilecektir. Bunlardan bir kısmı öğrencilerin öteki derslerde veya okul dışında hazırlayacakları araçlardır"'(MEB, 1949, s. 104).

Görüldüğü üzere geçmiş programlarda materyal kullanımı kadar, kullanılacak materyalin niteliğinin de önemi üzerinde durulmaktadır (MEB, 1949). Coğrafya konularının öğretiminde kullanılacak olan materyalin "yaparak-yaşayarak" öğrenmeye hizmet edecek düzeyde olmasına dikkat edilmesi gerektiği, aynı zamanda diğer derslerde ve okul dışında da hazırlayabilecekleri kadar işlevsel olması gerektiği üzerinde durulması dikkat çekici bir unsur olarak karşımıza çıkmaktadır.

Geçmişten günümüze sosyal bilgiler dersinde coğrafya konularının öğretiminde kullanılacak materyaller incelendiğinde, teknolojinin de ilerlemesiyle beraber materyallerin çağın gerekliliklerine uygun olarak değişim gösterdiği görülmektedir. Örneğin 1936 İlkokul Programında coğrafya defterinin kullanımı önerilirken (MEB, 1936), 2005 Sosyal Bilgiler Dersi Öğretim Programında simülasyon programları yer almıştır (MEB, 2005). Bu durum, geçmiş programlarda yer alan materyallerin daha basit kaynaklar olduğu ve kullanılması önerilen materyallerin zamanla daha zengin kaynaklara evirildiğini göstermektedir.

Konuyla ilgili olarak, coğrafya konularını öğretimine yönelik, dünyadaki örnekler incelendiğinde bir takım benzerliklerin ve farklılıkların olduğu görülmektedir. Sormaz'ın (2019) yaptı̆̆ çalışmada, Belçika'da coğrafya derslerinde; çeşitli madenlerden örnekler, anemometre, rölyef blokları gibi materyallerin kullanıldığı görülürken, Özşavlı'nın (2007) Türkiye ve $A B D^{\prime}$ de ki coğrafya öğretimini karşılaştırdığı çalı̧masında; fosil setleri, higrometre, stereoskop gibi farklı materyallerin de kullanıldığı görülmektedir. Öyle ki, coğrafya konularını öğretimine yönelik ülkelere göre materyal kullanımlarındaki değişiklik o ülkelerin eğitime ayırdığı bütçe ile de ilgilidir. Çünkü ülkelerin coğrafya dersi için kullanılacak materyallerin çeşitlilik göstermesinin birçok sebebi olabileceği gibi en yaygın sebebi arasında ülkelerin eğitime ayırdığı bütçe yer almaktadır (Sormaz, 2019).

Özetle öğrencinin dersi daha iyi anlamasını ve öğrenci merkezli bir hale gelmesini sağlayan materyallerin, coğrafya konularını öğretiminde önemi büyüktür. Dale'in yaşantı konisinde ele aldığı gibi işin içine ne kadar çok duyu organı hitap ederse öğrenme o kadar kolaylaşır (Göğebakan, 2018). Hali hazırda paralel, meridyen, eksen eğikliği ve benzeri soyut kavramları barındıran coğrafya konularının öğretiminde materyal kullanımı, öğrencinin daha kalıcı öğrenmeler sağlamasını desteklemektedir (Avşar, 2010; Başıbüyük ve Çıkılı, 2002; Karakuş, Palaz, Kılcan ve Çepni, 2012). Bu doğrultuda çalışmada, Cumhuriyetten günümüze kadar yer alan ilkokul ve ortaokul sosyal bilgiler programlarında coğrafya konularının 
öğretiminde kullanılması önerilen materyallerin gösterdiği gelişim sürecinin ortaya konulması amaçlanmaktadır.

\section{YÖNTEM}

\section{Araştırmanın Modeli}

Araştırmada, tarama modeli içinde yer alan tarihsel yöntem kullanılmıştır. Geçmişte ve halen var olan bir durumu mevcut şekliyle betimlemeyi amaçlayan tarama yöntemi (literatür taraması), araştırma probleminin seçilerek anlaşılmasına ve araştırmanın tarihsel bir perspektife oturtulmasına yardımcı olur (Karasar, 2006). Bu bakımdan araştırmada, cumhuriyetten günümüze sosyal bilgiler programlarında coğrafya öğretimi için kullanılan materyallerin incelenmesi amaçlandığından bu yöntem benimsenmiştir.

\section{Veri Toplama Araçları}

Araştırmanın amacı doğrultusunda, veri toplama yöntemi olarak "doküman incelemesi" yöntemi kullanılmıştır. Doküman incelemesi, araştırılması hedeflenen olgu veya olgular hakkında bilgi içeren yazılı materyallerin analizini kapsar (Yıldırım ve Şimşek, 2016). Bu doğrultuda Cumhuriyetten günümüze kadar yayınlanmış olan ilkokul (1924, 1930, 1936, 1948, 1962, 1965, 1968, 1971) ve ortaokul programları $(1931-32,1938,1949,1998)$ ile ilköğretim $(2005,2018)$ sosyal bilgiler programları Talim Terbiye Kurulu Başkanlığı ve Milli kütüphane gibi kurumlardan toplanmıştır. Kaynak toplama süreci tamamlandıktan sonra incelemelere başlanmış ve kaynaklar kronolojik olarak incelenmiştir. İncelenen ilk mektep/ilkokul, orta mektep/ortaokul ve ilköğretim programlarına aşağıdaki tabloda yer verilmiştir.

Tablo 1.

Coğrafya Dersi Kapsamında İncelenen Öğretim Programları

\begin{tabular}{|c|c|c|c|}
\hline Düzey & Öğretim Programı & Ders & \\
\hline \multirow{9}{*}{ İlk Mektep/İlkokul } & 1924 İlk Mekteplerin & $\begin{array}{ll}\text { Musahabat-1 } & \text { Ahlakiye }\end{array}$ & ve \\
\hline & Programı & Malumat-I Vataniye & \\
\hline & 1930 İlk Mektep Müfredat Programı & Coğrafya & \\
\hline & 1936 İlkokul Programı & Coğrafya & \\
\hline & 1948 İlkokul Programı & Coğrafya & \\
\hline & 1962 İlkokul Program Taslağı & Toplum ve Ülke İncelemeleri & \\
\hline & 1965 İlkokul Programı & Toplum ve Ülke İncelemeleri & \\
\hline & 1968 İlkokul Programı & Sosyal Bilgiler & \\
\hline & 1971 İlkokul Programı & Sosyal Bilgiler & \\
\hline \multirow{4}{*}{$\begin{array}{l}\text { Orta } \\
\text { Mektep/Ortaokul }\end{array}$} & 1931-32 Orta Mektep Müfredat & Coğrafya & \\
\hline & Programı & & \\
\hline & 1938 Orta Okul Programı & Coğrafya & \\
\hline & 1949 Orta Okul Programı & Coğrafya & \\
\hline \multicolumn{2}{|c|}{1998 İlköğretim Okulu Programı } & Sosyal Bilgiler & \\
\hline \multicolumn{2}{|c|}{2005 İlköğretim Sosyal Bilgiler Programı } & Sosyal Bilgiler & \\
\hline \multicolumn{2}{|c|}{2018 İlk ve Ortaöğretim Sosyal Bilgiler Programı } & Sosyal Bilgiler & \\
\hline
\end{tabular}

\section{Verilerin Analizi}

Araştırmada, alan yazın taraması sonucunda elde edilen veriler betimsel analiz yöntemi ile analiz edilmiştir. Betimsel analiz yöntemine göre veriler önceden belirlenmiş temalara göre (yıl, ders ve araç gereç durumu) yorumlanır. Amaç elde edilen verileri, yorumlanmış ve düzenlenmiş bir şekilde ortaya koymaktır (Yıldırım ve Şimşek, 2016). Araştırmanın veri 
analizi sürecinde dokümanlar eş zamanlı olarak araştırmacılar ve farklı bir alan uzmanı tarafından incelenmiş ve değerlendirilmiştir.

\section{BULGULAR}

\section{1. İlkokul Öğretim Programlarında Araç Gereçlerin Kullanımına İlişkin Bulgular}

Tablo 2.

İlkokul Programlarındaki Araç Gereç Kullanımı

\begin{tabular}{|c|c|c|}
\hline Yillar & Ders & Araç Gereçler \\
\hline 1924 & $\begin{array}{l}\text { Musahabat-1 Ahlakiye } \\
\text { ve Malumat-I Vataniye }\end{array}$ & Harita, kroki, menkıbeler (hikâye) \\
\hline 1930 & Coğrafya & $\begin{array}{l}\text { Duvar haritaları, küre, atlas, harita, kabartma haritaları, resimler, } \\
\text { levhalar, kartpostallar, sınıf müzesi, sinema ve projeksiyon, } \\
\text { taslaklar ve maktalar, coğrafya defteri, eşya örnekleri }\end{array}$ \\
\hline 1936 & Coğrafya & $\begin{array}{l}\text { Harita, kum havuzu, şehir planları, atlas, küre, grafikler, } \\
\text { coğrafya defteri, yardımcı eserler, resimler, tablo, kartpostal, } \\
\text { eşya örnekleri, fotoğraf, krokiler }\end{array}$ \\
\hline 1948 & Coğrafya & $\begin{array}{l}\text { Harita, kum masası, şehir planları, atlaslar, yer küre, grafikler, } \\
\text { coğrafya defteri, yardımcı eserler, resim ve eşya koleksiyonları }\end{array}$ \\
\hline 1962 & $\begin{array}{l}\text { Toplum ve Ülke } \\
\text { İncelemeleri }\end{array}$ & $\begin{array}{l}\text { Akvaryum, teraryum, saksılar, kafesler, insektaryum, metre, } \\
\text { büyüteç, hava gözlem aletleri, saat, kum masası, planlar, okul } \\
\text { tabiat köşesi, okul uygulamaları bahçesi, hayvanlar, bitkiler, } \\
\text { atlas, yerküre, grafik, coğrafyaya yardımcı eserler, resim ve eşya } \\
\text { koleksiyonu }\end{array}$ \\
\hline 1965 & $\begin{array}{l}\text { Toplum ve Ülke } \\
\text { İncelemeleri }\end{array}$ & $\begin{array}{l}\text { Modellemeler, levha, haritalar, plan, kroki, broşür, bülten } \\
\text { tahtası, dürbün, tahta, kil, plastik, kâğıtt, karton, teyp, diktafon } \\
\text { (ses kayıt cihazı), diyapozitif (slayt) }\end{array}$ \\
\hline 1968 & Sosyal Bilgiler & $\begin{array}{l}\text { Tabiat köşesi, akvaryum, teraryum, kafesler, metre, büyüteç, } \\
\text { hava gözlem aleti, saat, kum masası, planlar, takvim, } \\
\text { termometre, saat kadranı, pergel, gönye, cetvel tahtası, okul } \\
\text { uygulama bahçesi, tablo, haritalar, levhalar, fotoğraflar, kıyafet, } \\
\text { yerküre, pusula, düzlem küre, kasaba ve şehir planı, yağmur } \\
\text { ölçüsü, barometre, rüzgâr fırıldağı ve oku, güneş sistemi basit } \\
\text { model, dergi, gazete }\end{array}$ \\
\hline
\end{tabular}

1971 Sosyal Bilgiler

-

2005 Sosyal Bilgiler

2018 Sosyal Bilgiler
Grafik, istatistik, tablo, haritalar, levhalar, fotoğraflar, yerküre, düzlem küre, pusula, şehir planları, termometre, yağmur ölçüsü, barometre, güneş sistemi basit model, rüzgâr fırıldağı ve oku Çalışma Kâğıdı, haritalar, fotoğraflar, filmler, CD romlar, simülasyon programları, multimedya, hipermedya, internet araçları, resim, proje, poster, şarkı sözü, powerpoint sunusu, maket, görsel materyaller, atlas, kavram haritası, öğrenci ürün dosyası, gazete, dergi, renkli kalem, tablo, grafikler, cetvel, pergel, milimetrik kağıt

Harita, tablo, grafik, diyagram, yön bulma araçları, kroki, hava gözlem araçları, şiir, hikâye, destan, deprem çantası, görsel materyaller, görsel ve yazılı iletişim araçları

Tablo 2' de ilkokul programlarında sosyal bilgiler dersinde coğrafya konularının öğretimi için kullanılan araç gereçler incelenmiştir. Derslerin isim değişikliğinin yıllara göre 
gözlemlendiği bu tabloda bazı derslerin bazı yıllarda farklı isimlerle yer aldığı veya bu derse yer verilmediği görülmektedir. 1924 yılında tarih, coğrafya, hayat bilgisi/yurt bilgisi, vatandaşlık, hukuk/ekonomi dersleri bulunmaktadır. Coğrafya dersinde kullanılacak araç gereçlere bakıldığında harita, kroki ve menkıbeler (hikâye) yer almaktadır. Buna göre Cumhuriyet döneminin ilk programı olan 1924 İlk Mektep Müfredat Programında yer alan materyallerin sayıca az olduğu görülmektedir. 1930 yılında hayat bilgisi, tarih, coğrafya, yurt bilgisi dersleri bulunmaktadır. Coğrafya dersinde kullanılacak araç gereçlere bakıldığında küre, sinema, projeksiyon, levhalar, atlas vb. yer almaktadır. 1936 yılında yer alan dersler ise tarih, coğrafya, yurt bilgisi ve hayat bilgisidir. Coğrafya dersinde kullanılacak araç ve gereçlerde kum havuzu, şehir planları, grafikler, coğrafya defteri vb. yer almaktadır. 1948 yılında hayat bilgisi, tarih, coğrafya ve yurttaşlık bilgisi dersleri bulunmaktadır. Coğrafya dersinde kullanılan araç gereçler ise kum masası, yardımcı eserler, resim, eşya koleksiyonları vb. yer almaktadır. 1962 yılında toplum ve ülke incelemeleri dersi bulunmaktadır. Bu dersten coğrafya ile ilgili kullanılabilecek araç gereçlere bakıldığında akvaryum, içinde bitki ve böcek gibi farklı hayvanların bulunduğu akvaryum benzeri bir materyal olan teraryum, böceklerin incelenmesi amacıyla konulduğu, "böcek evi" de diyebileceğimiz bir materyal olan insektaryum, hava gözlem aletleri vb. yer almaktadır. 1965 yılında toplum ve ülke incelemeleri dersi bulunmaktadır. Coğrafya ile ilgili kullanılabilecek araç gereçlere bakıldığında kil, diktafon, diyapozitif (slayt) vb. yer almaktadır.

1968 yılına gelindiğinde sosyal bilgiler dersinin bulunduğu görülmektedir. Coğrafya ile ilgili kullanılabilecek araç gereçlerde ise tabiat köşesi, pusula, termometre, rüzgâr fırıldağı ve oku gibi materyaller yer almaktadır. 1971 yılında da sosyal bilgiler dersi bulunmaktadır. Coğrafya ile ilgili kullanılacak araç gereçler güneş sistemi basit modeli, yağmur ölçüsü, barometre vb. olarak yer almaktadır. 2005 yılında ve 2018 yılında yine sosyal bilgiler dersi bulunmaktadır. 2005 yılında sosyal bilgiler dersinde coğrafya öğretimi için kullanılabilecek araç gereçler simülasyon programları, CD ROM, multimedya, hipermedya vb. olarak verilmiştir. 2018 yılında sosyal bilgiler dersinde coğrafya öğretimi için kullanılabilecek araç gereçler ise görsel ve yazılı iletişim araçları, şiir, hikâye, destan, yön bulma araçları vb. olarak yer almıştır.

Buna göre genel olarak incelendiğinde; 1924 İlk Mektep Müfredat Programında diğer programlara oranla materyal sayısının az olduğu görülürken, 1930 İlkokul Programında bu sayının artış gösterdiği görülmektedir. Dönemin koşulları göz önünde bulundurulduğunda sinema ve projeksiyon gibi farklı materyallerin yer aldığı 1930 programından, 1962 programına kadar hazırlanmış programlarda 1-2 farklılık harici materyal çeşitliliği görülmezken, 1962 programında akvaryum, teraryum, insektaryum gibi daha önceki programlarda yer almamış birçok materyalin yer aldığı bulgusuna ulaşılmıştır. 1965 yılında ülke ve toplum incelemeleri adı altında okutulmaya başlanan dersin coğrafya konuları ile ilgili materyallerinde teyp, diktafon ve diyapozitif gibi farklı materyallerin yer aldığ görülürken, 1968 ve 1971 İlkokul Programlarında önceki programlarda bulunan materyaller ve farklı birkaç materyalin yanında klasikleşmiş araç- gereçlerin yer aldığ 1 görülmektedir. 2005 programında ise yapılandırmacı anlayışın da etkisiyle birlikte kullanılan araç gereçlerde gözle görülen bir artışın olduğu fark edilmektedir. Ayrıca önceki programlarda yer alan materyallerden farklı olarak simülasyon programları, multimedya, hipermedya ve internet araçları gibi materyallerin yer alması, teknolojinin ilerlemesinin getirdiği etkiyle beraber dijital materyallerin programlara girmeye başladığını göstermektedir. Günümüzde öğretimi 
halen devam eden 2018 programında ise materyallerin sayısının bir önceki programdan az olması ve dijital materyallerin 2005 programına göre sınırlı kalması ise dikkat çekici bir ayrıntı olarak göze çarpmaktadır.

\section{Ortaokul Öğretim Programlarında Araç Gereç Kullanımına İlişkin Bulgular}

Tablo 3.

Ortaokul Programlarındaki Araç Gereç Kullanımı

\begin{tabular}{|c|c|c|}
\hline Yillar & Ders & Araç Gereçler \\
\hline $1931-32$ & Coğrafya & $\begin{array}{l}\text { Harita, atlas, küre, sıra, levhalar, kartpostal, dergi, gazete, } \\
\text { resimler, iş masası, cetvel, gönye, pergel, resim kalemi, fırça, çin } \\
\text { mürekkebi, kuru-sulu boya, pusula, barometre, ölçü şeridi, } \\
\text { planlar, şahıs ve ölçü zincirleri, projeksiyon, cam, sabit filmler, } \\
\text { harita kalıpları, diyagram, portfolyo, su tesviyesi }\end{array}$ \\
\hline 1938 & Coğrafya & $\begin{array}{l}\text { Harita, küre, levha, kartpostal, dergi, gazete, resimler, atlas, } \\
\text { istatistik, coğrafya okumaları, masa, kil, kum, alçı, cetvel, gönye, } \\
\text { pergel, resim kalemi, fırça, çin mürekkebi, kuru-sulu boya, } \\
\text { pusula, barometre, plan, projeksiyon cihazı, coğrafyaya ait } \\
\text { camlar, harita kalıpları }\end{array}$ \\
\hline 1949 & Coğrafya & $\begin{array}{l}\text { Harita, resim, grafik, diyagram, kroki, planlar, yer küre, atlas, } \\
\text { kum masası, eşya ve ürün koleksiyonu, defter, kum havuzu }\end{array}$ \\
\hline 1998 & Sosyal Bilgiler & $\begin{array}{l}\text { Harita, plan, kroki, grafik, konuya uygun araç gereç yapımı, olay } \\
\text { yazıları, resimler, istatistiki veriler, gazete, dergi }\end{array}$ \\
\hline
\end{tabular}

Tablo 3'te ortaokul programında araç gereçlerin kullanım durumu incelendiğinde; 1931-32, 1938, 1949 ve 1998 programlarının yer aldığ1 görülmektedir. 1931-32 programında yurt bilgisi, tarih ve coğrafya dersleri bulunmaktadır. Coğrafya dersinde kullanılan araç gereçler; iş masası, çin mürekkebi, harita kalıpları vb. yer alırken yine aynı derslerin bulunduğu 1938 programında alçı, coğrafyaya ait camlar ve projeksiyon cihazı; 1949 programında ise diyagram, kroki, yer küre, eşya ve ürün koleksiyonu gibi araç gereçler yer almaktadır. 1998 yılında sosyal bilgiler dersi bulunmaktadır. Coğrafya öğretimi için kullanılabilecek araç gereçlere bakıldığında gazete, dergi, kroki, resimler vb. yer almaktadır.

Buna göre genel olarak incelendiğinde; 1931-32 ve 1938 Ortaokul Programlarında coğrafya konularının öğretiminde çin mürekkebi ve projeksiyon gibi araç gereçlerin dikkat çekmesinin yanında, programlarda kullanılması önerilen materyallerin önceki yıllara göre sayıca çokluğu göze çarpmaktadır. Bununla beraber 1949 ve 1998 Ortaokul Programlarında, diğer programlara oranla materyal sayısı azalma göstermiştir.

\section{SONUÇ VE TARTIŞMA}

Cumhuriyetten günümüze kadar hazırlanan sosyal bilgiler dersi öğretim programlarında coğrafya öğretiminde yer alan materyal durumu genel olarak değerlendirildiğinde; 1924 İlk Mektep Müfredat Programında harita, kroki ve menkıbeler (hikaye); 1930 ìlkokul Programında sinema ve projeksiyon; 1938 Ortaokul Programında kil ve alçı; 1962 İlkokul Programında akvaryum, teraryum, insektaryum, okul tabiat köşesi; 1968 İlkokul Programında rüzgar fırıldağı ve oku; 1971 İlkokul Programında güneş sistemi basit modeli; 1998 Ortaokul Programında olay yazıları; 2005 İlköğretim Programında CD romlar, 
simülasyon programları, multimedya, hipermedya; 2018 İlkokul ve Ortaokul Programlarında ise şiir, destan, deprem çantası gibi materyallerin yer aldığı görülmektedir.

Araştırmanın birinci alt problemine göre sosyal bilgiler dersi ilkokul programlarında, coğrafya konularının öğretiminde kullanılan materyaller incelendiğinde; 1924 yılında kullanılan materyallerin sayıca az olduğu görülmektedir. Eğitimde materyal kullanımını etkileyen etmenlerin başında ülkelerin eğitime ayırdığı bütçe gelmektedir (Sormaz, 2019). Çalışmanın bulgusunu destekler nitelikte olan Ayvaz'ın (2012) çalışmasında benzer bir bulguya ulaşılmakta ve devletin bütçesinin az olduğu yıllardan biri olarak 1924 yılının program içeriğini etkilediği belirtilmektedir. Ayrıca Ertuna'nın (2004) çalışmasından yola çıkılarak, Cumhuriyetin henüz yeni kurulmuş olmasının getirdiği birçok sorunla birlikte zayıf ekonominin de bu durumu etkilediği belirtilmektedir. 1930 İlkokul Programında, sinema, projeksiyon, taslaklar, maktalar ve coğrafya defteri yer alırken, 1948 İlkokul Programında ise kum masası, şehir planları, atlaslar gibi materyaller yer almaktadır. 1962 İlkokul Programında coğrafyaya yardımcı eserler, resim ve eşya koleksiyonu yer alırken, 1968 İlkokul Programında rüzgâr fırıldağı, oku ve güneş sistemi basit modeli gibi materyaller bulunmaktadır. Ambarlı'nın (2010) Cumhuriyetten günümüze sosyal bilgiler programlarındaki değişikleri, düzenlemeleri ve güncellemeleri incelediği araştırmasında, 1930, 1948, 1962 ve 1968 İlkokul Programlarında incelediği coğrafya materyalleri araştırma ile örtüşmektedir. 2005 Sosyal Bilgiler Öğretim Programında materyal sayısının arttığı; filmler, CD romlar, simülasyon programları, multimedya, hipermedya, internet araçları, proje, poster gibi materyallerin yer aldığ 1 görülmektedir. Bu durumda derslerin materyal kullanımına daha elverişli hale gelmesiyle beraber materyal sayısının artış gösterdiğini söylemek mümkündür. Nitekim Demiralp'in (2007) çalışması da bu görüşü desteklemektedir. Demiralp (2007), 2005 yılında yapılandırmacı yaklaşımın hakim olduğu bir programın uygulamaya girmesi ile birlikte derslerde materyal kullanımının önemli hale gelmiş olduğunu ifade etmektedir.

Coğrafya konularına yönelik incelediğimiz tüm ortaokul programlarında "harita" materyalinin yer aldığ 1 görülmektedir. Bu sonuca dayanarak derslerde en çok kullanılması önerilen materyallerden birinin "harita" olduğunu söylemek mümkündür. Bu görüşü destekler nitelikte olan Darakçı (2014), sosyal bilgiler öğretim programını ve ders kitaplarında ki harita kullanımını incelediği çalışmasında, sosyal bilgiler programında sıklıkla harita kullanımının yer aldığı bulgusuna ulaşmıştır. Çoban ve İleri'nin (2013) sosyal bilgiler öğretmenlerinin öğretim teknolojilerini ve materyalleri kullanma düzeyleriyle, bu materyalleri kullanamama sebeplerine yönelik yaptıkları araştırmalarında ise, öğretmenlerin sık kullandıkları materyaller arasında internet, bilgisayar, projeksiyon ve harita olduğu görülmektedir. Çalışmada, 2005 Sosyal Bilgiler Dersi Öğretim Programında önerilen materyaller arasında, internet ve harita yer alırken projeksiyon ve bilgisayar yer almamaktadır. Ancak teknolojinin ilerlemesinin getirdiği etkiyle beraber projeksiyonun yerini simülasyon programları, multimedya, hipermedya gibi araçların aldığını söylemek mümkündür. Öte yandan yine çalışmada incelenen 2005 programında, coğrafya öğretimi ile ilgili konularının büyük çoğunluğunda harita materyalinin kullanımının önerildiği görülmektedir. Bu durum derslerde öne çıkan materyalin çoğunlukla "harita" olduğu sonucuna ulaşmamızı gösterebilmektedir. Nitekim Duman'ın (2011) sosyal bilgiler dersinde haritaların kullanımı ve harita kullanımı açısından öğretmen görüşlerini belirlemek için yaptığı çalışmasında, okullarda öğrenci düzeyine uygun haritaların varlığı, oluşturulan haritaların yeterli ve güncel olduğu ifade edilmektedir. Bununla birlikte 2005 Sosyal Bilgiler 
Dersi Öğretim Programında da harita kullanımının yeterince desteklendiği ve ders kitaplarında harita kullanımıyla ilgili etkinliklerin yeterli oranda yer aldığının ortaya konulması çalışmanın verilerini destekler niteliktedir.

2018 Sosyal Bilgiler Dersi Öğretim Programında, 2005 programına göre coğrafya materyallerinin sayısında gözle görülür bir azalma fark edilirken; harita, şiir, destan, deprem çantası gibi materyallerin yer aldığı görülmektedir. Alan yazın incelendiğinde ise benzer olarak Şanlı'nın (2018) ortaokul öğrencilerinin sosyal bilgiler dersinde kullanılan materyallere ilişkin görüşlerini belirlemeye yönelik yaptığı çalışmasında, derslerde kullanılan materyalleri akıllı tahta, atlas, harita, defter ve kitap olarak ortaya konulduğu görülmektedir. Çalışmanın 2018 programının incelendiği kısmında ise çalışmanın verilerinden farklı olarak, Şanlı'nın (2018) çalışmasında öğrencilerin söyledikleri materyallerden yalnızca haritanın yer aldığı, akıllı tahta ve atlas materyallerinin programda yer almadığı fakat bu araç gereçlerin derslerde kullanıldığı bulgusuna ulaşılmaktadır. Aydemir'in (2012) sosyal bilgiler öğretmenlerinin öğretim araç ve gereçlerini kullanım düzeylerini belirlemeye yönelik yaptığı çalışmasında ise en çok kullanılan materyaller arasında yazı tahtası, harita ve küre olduğu görülmektedir. Çalışmanın kaynaklarını oluşturan çoğu programda harita ve kürelerin yer aldığı görülmektedir. Ancak Aydemir'in (2012) elde ettiği bulgularda öğretmenlerin en çok kullandığı materyallerden birinin küre olması, araştırmanın yapıldığı yıl bakımından 2005 öğretim programının yürürlükte olması, ancak 2005 Sosyal Bilgiler Dersi Öğretim Programı'nda küre materyalinin yer almaması dikkat çekicidir.

Sosyal bilgiler dersi ortaokul programlarında, coğrafya konularının öğretiminde kullanılan materyaller incelendiğinde; 1949 Ortaokul Programında yer alan materyal sayısının sayıca azlığı göze çarpmaktadır. Ayvaz'ın (2012) çalışmasında, 1949 yılından 1950 yılına kadar olan dönemde MEB'e ayrılan bütçenin en yüksek bütçe olduğu görülmektedir. Buna rağmen 1949 Ortaokul Programında ki materyal sayısının diğer programlara oranla nispeten daha az olması dikkat çekici bir sonuçtur.

Çalışmanın sonuçları genel olarak değerlendirildiğinde; incelenen programların ders kitaplarında bulunan, sosyal bilgiler dersinde coğrafya konularının öğretimine yönelik araçgereç kullanım durumları incelenebilir. Ayrıca sosyal bilgiler ders kitaplarında yer alan araç gereç kullanım durumunun yıllara göre karşılaştırmalı olarak ele alınabileceği araştırmalar da önerilebilir.

\section{KAYNAKÇA}

Ambarlı, A. (2010). Türkiye'de cumhuriyetten günümüze sosyal bilgiler programları (değişiklikler, düzenlemeler, güncellemeler). (Yayımlanmamış yüksek lisans tezi), Selçuk Üniversitesi Eğitim Bilimleri Enstitüsü, Konya.

Avşar, S. (2010). İlköğretim ikinci kademe sosyal bilgiler derslerinde coğrafya konularının öğretiminde materyal kullanımının öğrenci başarısına etkisi. (Yayımlanmamış yüksek lisans tezi), Selçuk Üniversitesi Eğitim Bilimleri Enstitüsü, Konya.

Aydemir, H. (2012). Sosyal bilgiler öğretmenlerinin öğretim araç-gereçleri kullanım düzeyleri. Cumhuriyet Üniversitesi Edebiyat Fakültesi Sosyal Bilimler Dergisi, 36 (1), 163 182. 
Ayvaz, S. (2012). Cumhuriyet dönemi eğitim bütçeleri. (Yayımlanmamış yüksek lisans tezi), Dokuz Eylül Üniversitesi Eğitim Bilimleri Enstitüsü. İzmir.

Başıüyük, A. ve Çıkılı, Y. (2002). İlköğretim 6. ve 7. sınıf sosyal bilgiler coğrafya konularında çalışma yaprağı ve dilsiz harita kullanımının öğrenci motivasyon ve başarısı üzerine etkisi. Marmara Üniversitesi Atatürk Ĕ̆itim Fakültesi Eğitim Bilimleri Dergisi, 16 (16) , 29-38

Çetin, H. ve Gülseren, H. Ö. (2003). Cumhuriyet dönemi eğitim stratejileri. Milli Eğitim Dergisi, 160.

Çoban, A. ve İleri, T. (2013). Sosyal bilgiler öğretmenlerinin öğretim teknolojileri ve materyalleri kullanma düzeyleri ve kullanamama sebepleri. Amasya Üniversitesi Eğitim Fakültesi Dergisi, 2 (1) , 194-213.

Darakçı, S. (2016). Sosyal bilgiler öğretim programı ve ders kitaplarında harita kullanımı. Mehmet Akif Ersoy Üniversitesi Ĕ̆itim Bilimleri Enstitüsü Dergisi, 3 (4) , 15-31.

Demiralp, N. (2007). Coğrafya eğitiminde materyaller ve 2005 coğrafya dersi öğretim programı. Kastamonu Ĕ̆itim Dergisi, 15 (1), 373-384.

Demirel, Ö. (2013). Eğitimde program geliştirme (20. Bask1). Ankara: Pegem Akademi.

Duman, H. (2011). Sosyal bilgiler eğitiminde harita kullanımı ve harita kullanımı konusunda öğretmen görüşleri. (Yayımlanmamış yüksek lisans tezi), Uludağ Üniversitesi Eğitim Bilimleri Enstitüsü, Bursa.

Ertuna, Ö. (2004). 1923'ten bugüne Türkiye ekonomisi ve 2023'e doğru hedefler. Muhasebe ve Finansman Öğretim Üyeleri Bilim ve Araştırma Derneği Muhasebe ve Finans Dergisi, 21, 617

Göğebakan, Y. (2018). Alternatif öğrenme mekânları olarak müzelerin eğitim-öğretimde kullanılmasının önemi. Güzel Sanatlar Enstitüsü Dergisi, (40) , 9-41.

Karabacak, Ö. (2009). II. Dünya Savaşı yıllarında uygulanan eğitim ve kültür politikalarının taşradaki yansımaları: Aydın ili örneği. (Yayımlanmamış yüksek lisans tezi), Adnan Menderes Üniversitesi Sosyal Bilimler Enstitüsü, Aydın.

Karakuş, U., Palaz, T., Kılcan, B., ve Çepni, O. (2012). Sosyal bilgiler müfredatında yer alan "çevre sorunları" konularının öğretiminde karikatür kullanımının öğrencilerin akademik başarısına etkisi. Gazi Üniversitesi Gazi Ĕ̆itim Fakültesi Dergisi, 32 (2), 363376.

Karasar, N. (2006). Bilimsel araştırma yöntemi (16. Baskı). Nobel Yayıncılık: Ankara.

Kaya, H. ve Aydın, F.(2011). Sosyal bilgiler dersindeki coğrafya konularının öğretiminde akıllı tahta uygulamalarına ilişkin öğrenci görüşleri. Zeitschrift für die Welt der Türken I Journal of World of Turks, 3 (1).

Kaya, N. ve Önal, H. (2019). 12 Eylül 1980 askeri darbesinin coğrafya öğretim programı ve ders kitaplarına yansıması. Milli Eğitim Dergisi, 48 (223) , 283-298.

Kaymak, B. (2019). Sosyal bilgiler öğretmen adaylarının lisans eğitiminde tarihsel roman kullanımına ilişkin görüşleri. Journal of Innovative Research in Social Studies, 2 (1), 1-15. 
Kılıç, A. (2020). 27 Mayıs 1960 darbesinin eğitim hayatına etkileri. Alınteri Sosyal Bilimler Dergisi, 4 (2) , 89-110.

Maarif Vekâleti (1924). Illk mekteplerin müfredat programı. İstanbul: Matbaa-i Amire.

Maarif Vekâleti (1930). İlk mektep müfredat programı. İstanbul: Devlet Matbaaları.

Maarif Vekâleti (1931). Orta mektep müfredat programı. İstanbul: Devlet Matbaaları.

Maarif Vekâleti (1936). Illk mektep müfredat programı. İstanbul: Devlet Matbaaları.

Maarif Vekâleti (1938). Ortaokul Programı. İstanbul: Devlet Basımevi.

MEB. (1948). İlkokul programı. İstanbul: Milli Eğitim Basımevi.

MEB. (1949). Ortaokul programı. İstanbul: Milli Eğitim Basımevi.

MEB. (1962). İlkokul programı. İstanbul: Milli Eğitim Basımevi.

MEB. (1965). İlkokul programı. İstanbul: Milli Eğitim Basımevi.

MEB. (1968). İlkokul programı. İstanbul: Milli Eğitim Basımevi.

MEB. (1971). İlkokul programı. İstanbul: Milli Eğitim Basımevi.

MEB. (1998). Ortaokul Programı. Ankara: Milli Eğitim Yayınları.

MEB. (2005). İlköğretim sosyal bilgiler dersi öğretim programı ve kılavuzu. Ankara: Milli Eğitim Yayınları.

MEB. (2018). İlköğretim sosyal bilgiler dersi öğretim programı ve kılavuzu. Ankara: Milli Eğitim Yayinları.

Nalçacı, A. ve Ercoşkun, M. (2005). İlköğretim sosyal bilgiler derslerinde kullanılan materyaller. Atatürk Üniversitesi Kazım Karabekir Eğitim Fakültesi Dergisi, 0 (11) , 141154.

Özşavlı, C. (2007). I. coğrafya kongresinden günümüze Türkiye'de lisede okutulan coğrafya dersi müfredatında yapılan değişiklikler ve ülkemizdeki ile Amerika birleşik devletlerindeki coğrafya öğretiminin karşılaştırılması (Yayımlanmamış yüksek lisans tezi), Selçuk Üniversitesi Sosyal Bilimler Enstitüsü, Konya.

Seferoğlu, S. (2006). Öğretim teknolojileri ve materyal tasarımı (3. Baskı). Ankara: Pegem Akademi.

Sormaz, M. (2019). İsveç'te coğrafya eğitim öğretiminin müfredat, metot ve araç-gereç açısından değerlendirmesi. (Yayımlanmamış yüksek lisans tezi), Marmara Üniversitesi Eğitim Bilimleri Enstitüsü, İstanbul.

Şahin, S., Gençtürk, E., ve Budanur, T. (2007). Coğrafya öğretiminde uygun grafik seçimi ve kullanımının öğrenme üzerindeki etkisi. Kastamonu Ĕ̆itim Dergisi, 15 (1), 293-302.

Şanlı, S. (2018). Ortaokul öğrencilerinin sosyal bilgiler derslerinde kullanılan öğretim materyallerine ilişkin görüşleri. Journal of Innovative Research in Social Studies, 1 (1), 52-64. 
Ulubey, Ö. ve Aykaç, N. (2017). Türkiye cumhuriyetin ilanından 2005'e eğitim felsefelerinin ilkokul programlarına yansıması. Mersin Üniversitesi Eğitim Fakültesi Dergisi, 13 (3), 1173-1202.

Yıldırım, A. ve Şimşek, H. (2016). Sosyal bilimlerde nitel araştırma yöntemleri (10. baskı). Ankara: Seçkin Yayınevi.

Yıldız, V. ve Kılıç, D. (2018). Sosyal bilgiler dersi öğretim programlarına ilişkin öğretmen görüşleri: bir meta-sentez çalışması. Atatürk Üniversitesi Sosyal Bilimler Enstitüsü Dergisi, 2115-2127.

Yalçın, A. ve Akhan, N. E. (2019). Cumhuriyetten günümüze sosyal bilgiler programlarının sosyal bilgiler öğretim yaklaşımlarına göre incelenmesi. Journal of Theoretical Educational Science, 12 (3), 842-873. 